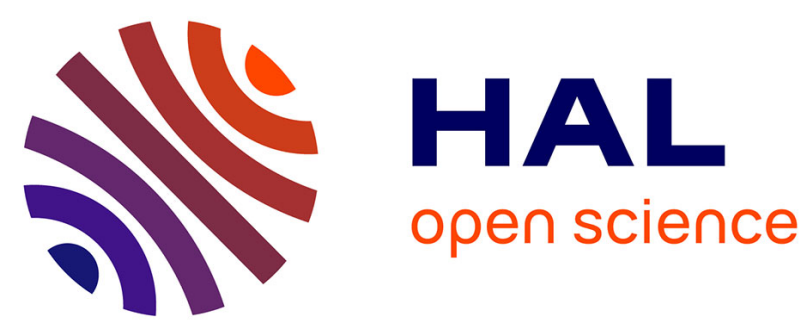

\title{
Ruthenium-Catalyzed C-H Bond Alkylation of Arylphosphine Oxides with Alkenes: A Straightforward Access to Bifunctional Phosphorous Ligands with a Pendent Carboxylate
}

\author{
C.-S. Wang, Pierre H. Dixneuf, Jean-François Soulé
}

\section{To cite this version:}

C.-S. Wang, Pierre H. Dixneuf, Jean-François Soulé. Ruthenium-Catalyzed C-H Bond Alkylation of Arylphosphine Oxides with Alkenes: A Straightforward Access to Bifunctional Phosphorous Ligands with a Pendent Carboxylate. ChemCatChem, 2017, 9 (16), pp.3117-3120. 10.1002/cctc.201700557 . hal-01581227

HAL Id: hal-01581227

https://hal-univ-rennes1.archives-ouvertes.fr/hal-01581227

Submitted on 4 Sep 2017

HAL is a multi-disciplinary open access archive for the deposit and dissemination of scientific research documents, whether they are published or not. The documents may come from teaching and research institutions in France or abroad, or from public or private research centers.
L'archive ouverte pluridisciplinaire HAL, est destinée au dépôt et à la diffusion de documents scientifiques de niveau recherche, publiés ou non, émanant des établissements d'enseignement et de recherche français ou étrangers, des laboratoires publics ou privés. 


\title{
Ruthenium-Catalyzed C-H Bond Alkylation of Arylphosphine Oxides with Alkenes: A Straightforward Access to Bifunctional Phosphorous Ligands with a Pendent Carboxylate
}

\author{
Chang-Sheng Wang, ${ }^{[a]}$ Pierre H. Dixneuf ${ }^{[a]}$ and Jean-François Soulé ${ }^{\star[a]}$
}

\begin{abstract}
An efficient approach for the fast modification of arylphosphine oxides involving ruthenium(II)-catalyzed $\mathrm{C}-\mathrm{H}$ bond alkylation with functional alkenes versus alkenylation has been developed depending on the acidic reaction conditions. A few examples of desymmetrization of diarylphosphine oxides containing three different substituents were prepared using this methodology. After reduction of the phosphine oxide, this method allows the formation of aryl phosphines bearing a flexible pendent carboxylate.
\end{abstract}

Arylphosphine oxides play a central role in organophosphorus chemistry. This motif is embedded in organic molecular materials, especially in the design of blue phosphorescent organic light-emitting diodes. ${ }^{[1]}$ In addition, phosphorus $(\mathrm{V})$ is an important bioisostere in medicinal chemistry, ${ }^{[2]}$ and among this class of compounds some aryl phosphine oxides have displayed useful biological activity. ${ }^{[3]}$ They are also essential in catalysis whether as organocatalysts $^{[4]}$ or as precursors of phosphine-metal catalysts. ${ }^{[5]}$

One of the most general methods for the preparation of arylphosphine oxides involves C-P bond formation. ${ }^{[6]}$ Since the discovery of transition-metal catalyzed $\mathrm{C}-\mathrm{H}$ bond functionalizations, novel synthetic schemes have been proposed for the preparation of complex molecules. ${ }^{[7],[8]}$ In this context, Shibata reported, the first example of $\mathrm{C}-\mathrm{H}$ bond ortho-alkenylation of ferrocenylphosphine oxide using an alkyne in the presence of an iridium catalyst (Scheme 1.a $)^{[9],[10]}$ Then, Satoh and Miura demonstrated that the $P=O$ bond of arylphosphine oxides could be more efficiently used as a directing group in rhodium(III)-catalyzed ortho- $\mathrm{C}-\mathrm{H}$ bond alkenylation with alkenes in the presence of $\mathrm{AgOAc}$ as oxidant (Scheme 1.b). ${ }^{[1]}$ Glorius has applied thus alkenylation to arylphosphonates and phosphonamides. ${ }^{[12]}$ Related transformations involving $\mathrm{P}-\mathrm{OH}^{[13]}$ or $\mathrm{P}-\mathrm{N}^{[14]}$ directed $\mathrm{C}-\mathrm{H}$ bond activation have also been reported. Other functionalizations of arylphosphine oxides such as $\mathrm{C}-\mathrm{H}$ bond amination, ${ }^{[15]}$ arylation, ${ }^{[16]}$ cyanation, ${ }^{[17]}$ are reported using noble transition metals. Ruthenium(II)-catalyzed direct

[a] Mr. C.-S. Wang, Prof. P. H. Dixneuf, Dr. J.-F. Soule Institut des Sciences Chimiques de Rennes, UMR 6226 CNRS-Université de Rennes "Organométalliques: Matériaux et Catalyse", Campus de Beaulieu, 35042 Rennes

Supporting information for this article is given via a link at the end of the document alkenylation of arylphosphine oxides with internal alkynes was further reported by Miura (Scheme 1.c). ${ }^{[18]}$ These pioneering results allowed new synthetic pathways for the preparation of bifunctional phosphine ligands containing a flexible pendent functionality, provided that alkylation selectivity with alkenes, rather than alkenylation, can be controlled. Ruthenium(II)-catalyzed functionalization of $\mathrm{C}-\mathrm{H}$ bonds with alkenes has preferentially led to alkenylation ${ }^{[19]}$ but some examples of alkylation, ${ }^{[20]}$ mostly directed by a pyridine group, have been reported. We report now the control and understanding of alkylation versus alkenylation of unreactive $\mathrm{C}-\mathrm{H}$ bond with phosphine oxide as directing group and their potential for the synthesis of functionalized phosphorous ligands (Scheme 1.d).

a. Ir-catalyzed ortho-alkenylation of ferrocenylphosphine oxide (Shibata) ${ }^{[9]}$

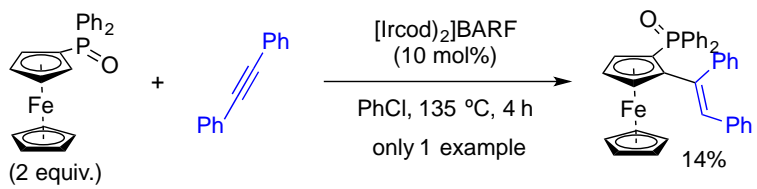

b. Rh-catalyzed ortho-alkenylation of arylphosphine oxides (Miura) ${ }^{[11]}$

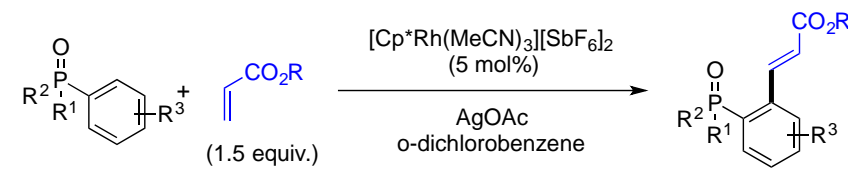

c. Ru-catalyzed ortho-alkenylation or alkylation of arylphosphine oxides (Miura) ${ }^{[18]}$

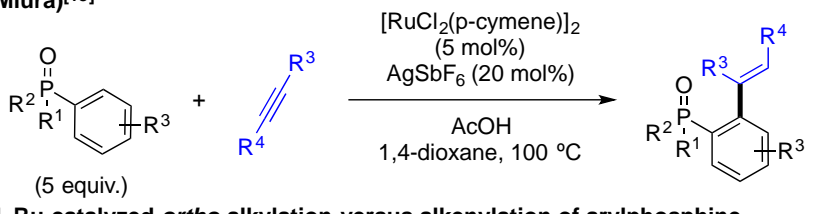

d. Ru-catalyzed ortho-alkylation versus alkenylation of arylphosphine oxides (this work)

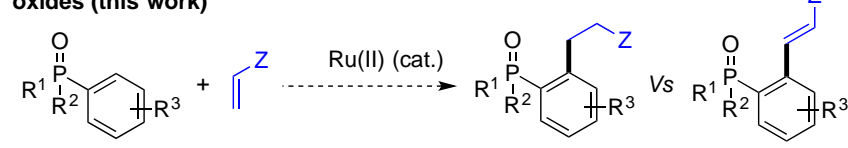

Scheme 1. Previous examples of TM-catalyzed direct alkenylation and/or alkylation of arylphosphine oxides

Miura and co-workers have reported beside alkenylation with alkyne (Scheme1.c) one example of the alkylation using triphenylphosphine oxide (1a) and $n$-butyl acrylate (2a) catalyzed by $\left[\mathrm{RuCl}_{2}(p \text {-cymene })\right]_{2}$ in concert with $\mathrm{AgSbF}_{6}$ in 
the presence 4 equivalents of 1 -adamantanecarboxylic acid $\left(\mathrm{AdCO}_{2} \mathrm{H}\right)$ in diglyme (Table 1 , entry 1$) .{ }^{[18]}$ We investigated the reaction parameters to influence the selectivity of the alkylation or alkenylation of $\mathbf{1 a}$ with the acrylate $\mathbf{2 a}$. 1,2Dichloroethane (DCE) as solvent displayed the best reactivity with the formation of 3aa in a higher yield of $65 \%$ without formation of 4 aa (Table 1, entries 2-4). When pivalic acid was used a comparable yield in 3aa was observed (Table 1, entry 5). However, using simple acetic acid, the yield of 3aa enhanced up to in $80 \%$. $\mathrm{Ru}(\mathrm{OAc})_{2}$ ( $p$-cymene) as the catalyst is inefficient (Table 1 , entry 7$)$. The alkylation of $1 \mathrm{a}$ with $2 \mathrm{a}$ was conducted on a gram scale to afford $1.9 \mathrm{~g}$ of 3aa (Table 1, entry 8). Having succeeded to obtain the alkylation product 3aa in both high yield and selectivity, we turned our attention the formation of the alkenylation product 4aa, which was not reported yet using ruthenium(II) catalysis albeit similar transformations were reported using rhodium(III) catalysis. ${ }^{[12,21]}$ In the presence of $\mathrm{Cu}(\mathrm{OAc})_{2}$ as oxidant, 4aa was formed in low yield but 3aa remained the major product (Table 1, entry 9). Changing the acid by a base, the formation of 3aa was inhibited and 4aa was obtained as the major product (Table 1, entries 10-14). $\mathrm{NaHCO}_{3}$ was selected as the best base to afford the alkenylated product $\mathbf{4 a a}$ in $\mathbf{4 8 \%}$ yield (Table 1, entry 14 ).

Table 1. Optimization of the reaction conditions

\begin{tabular}{|c|c|c|c|c|c|}
\hline $\begin{array}{c}\stackrel{\mathrm{O}}{\mathrm{Ph}_{3} \mathrm{P}}+ \\
\mathbf{1 a} \\
\text { (2 equiv.) }\end{array}$ & $\begin{array}{l}\mathrm{CO}_{2} n-\mathrm{Bu} \\
\mathbf{2 a}\end{array}$ & $\begin{array}{l}\left.\mathrm{RCl}_{2}(p \text {-cymene })\right]_{2} \\
\left(5 \mathrm{~mol}^{2}\right) \\
\mathrm{gSbF}_{6}(20 \mathrm{~mol} \%) \\
\text { Acid (x equiv.) } \\
\text { dditive (1 equiv.) } \\
\text { vent, } 120^{\circ} \mathrm{C}, 12 \mathrm{~h}\end{array}$ & & $\mathrm{CO}_{2} n-\mathrm{Bu}$ & 知 \\
\hline Entry & Additive $1(\mathrm{x})$ & Additive 2 & Solvent & 3aa $(\%)^{[a]}$ & 4aa $(\%)^{[a]}$ \\
\hline $1^{[18]}$ & $\mathrm{AdCO}_{2} \mathrm{H}(4)$ & - & diglyme & 58 & trace \\
\hline 2 & $\mathrm{AdCO}_{2} \mathrm{H}(4)$ & - & toluene & 13 & trace \\
\hline 3 & $\mathrm{AdCO}_{2} \mathrm{H}(4)$ & - & water & NR & NR \\
\hline 4 & $\mathrm{AdCO}_{2} \mathrm{H}(4)$ & - & DCE & 65 & trace \\
\hline 5 & $\mathrm{PivOH}(4)$ & - & DCE & 58 & trace \\
\hline 6 & $\mathrm{AcOH}(4)$ & - & DCE & $80(72)$ & trace \\
\hline $7^{[\mathrm{b}]}$ & $\mathrm{AcOH}(4)$ & - & DCE & $\mathrm{NR}$ & $N R$ \\
\hline $8^{[c]}$ & $\mathrm{AcOH}(4)$ & - & DCE & $63(1.9 \mathrm{~g})$ & trace \\
\hline 9 & $\mathrm{AcOH}(4)$ & $\mathrm{Cu}(\mathrm{OAc})_{2} \cdot \mathrm{H}_{2} \mathrm{O}$ & DCE & 71 & 11 \\
\hline 10 & $\mathrm{KH}_{2} \mathrm{PO}_{4}(1)$ & $\mathrm{Cu}(\mathrm{OAc})_{2} \mathrm{H}_{2} \mathrm{O}$ & DCE & 18 & 29 \\
\hline 11 & $\mathrm{~K}_{3} \mathrm{PO}_{4}(1)$ & $\mathrm{Cu}(\mathrm{OAc})_{2} \cdot \mathrm{H}_{2} \mathrm{O}$ & DCE & trace & 18 \\
\hline 12 & $\mathrm{Li}_{2} \mathrm{CO}_{3}(1)$ & $\mathrm{Cu}(\mathrm{OAc})_{2 .} \mathrm{H}_{2} \mathrm{O}$ & DCE & 5 & 35 \\
\hline 13 & $\mathrm{~K}_{2} \mathrm{CO}_{3}(1)$ & $\mathrm{Cu}(\mathrm{OAc})_{2} \mathrm{H}_{2} \mathrm{O}$ & DCE & trace & 12 \\
\hline 14 & $\mathrm{NaHCO}_{3}(1)$ & $\mathrm{Cu}(\mathrm{OAc})_{2} \mathrm{H}_{2} \mathrm{O}$ & DCE & trace & $53(48)$ \\
\hline
\end{tabular}

[a] Determined by GC-analysis using $n$-dodecane as internal standard, isolated yield is shown in parentheses.

${ }^{[b]} \mathrm{Ru}(\mathrm{OAc})_{2}\left(p\right.$-cymene) was used instead of $\left[\mathrm{RuCl}_{2}(p \text {-cymene })\right]_{2}$ and $\mathrm{AgSbF}_{6}$.

[c] Reaction performed from $1 \mathbf{a}(15.6 \mathrm{mmol}, 4.3 \mathrm{~g})$ and $2 \mathbf{a}(7.8 \mathrm{mmol}, 1 \mathrm{~g})$.

With the best conditions in hand (i.e. entry 6), we then investigated the scope of the alkylation of aryl phosphine oxides (Scheme 2). First, we explored the reactivity of some substituted triarylphosphine oxides with $n$-butyl acrylate. Tris( $p$-substituted phenyl)phosphine oxides with an electrondonating group such as methyl or methoxy allowed the formation of the ortho-alkylated triarylphosphine oxides $\mathbf{3 b a}$ and $3 \mathrm{ca}$ in $58 \%$ and $64 \%$ yields, respectively. Tris(4- fluorophenyl)phosphine oxide was also ortho-alkylated giving 3 da in good yield. However, the reaction seems to be very sensitive to the steric hindrance, as tri-o-tolylphosphine oxide was not reactive. Similarly to triarylphosphine oxides, benzyl(diphenyl)-phosphine oxide 1e and alkyl(diphenyl)phosphine oxide 1f underwent ortho-alkylation to afford the desired phosphine oxides 3ea and 3 fa in $63 \%$ and $47 \%$ yields, respectively. Methyl diphenylphosphinate $\mathbf{1 g}$ was ortho-alkylated to give $\mathbf{3 g a}$ in $53 \%$ yield. In these three examples, such late-stage modification affords a stereogenic phosphorus center which bears three different substituents, and provides a new synthetic pathway for the desymmetrization of arylphosphine oxides with the direct access to a potential new class of chiral phosphine. The reactivity of various electrophilic alkenes $(\mathbf{2 b}-\mathbf{d})$ with $\mathbf{1 a}$ or 1e were also examined. Good yields of $62 \%$ and $65 \%$ in ortho-alkylated arylphosphine oxides $\mathbf{3 a b}$ and $\mathbf{3 e b}$ were obtained from methyl acrylate (2b) and triphenylphosphine oxide (1a) and benzyl(diphenyl)-phosphine oxide (1e). Reaction of triphenylphosphine oxide (1a) with acrylonitrile (2c) gave a mixture of ortho-alkylation product 3ac and orthoalkenylation product $\mathbf{4 a c}$ in a 1:4 ratio. This lack of reactivity of acrylonitrile might be due to its strong coordination ability, which could prevent the $\mathrm{P}=\mathrm{O}$ coordination on the ruthenium. We also evaluated the reactivity of ethyl 3-phenylpropiolate (2d) and showed that the hydroarylation occurred to allow the regioselective formation of the ortho-alkenylated arylphosphine oxide 3 ad in $67 \%$ yield. In this case, only the $E$-isomer of 3ad was selectively obtained. This procedure offers a straightforward access to phosphine ligands containing a shorter (i.e., 4 carbons instead of 5) flexible pendent carboxylate.

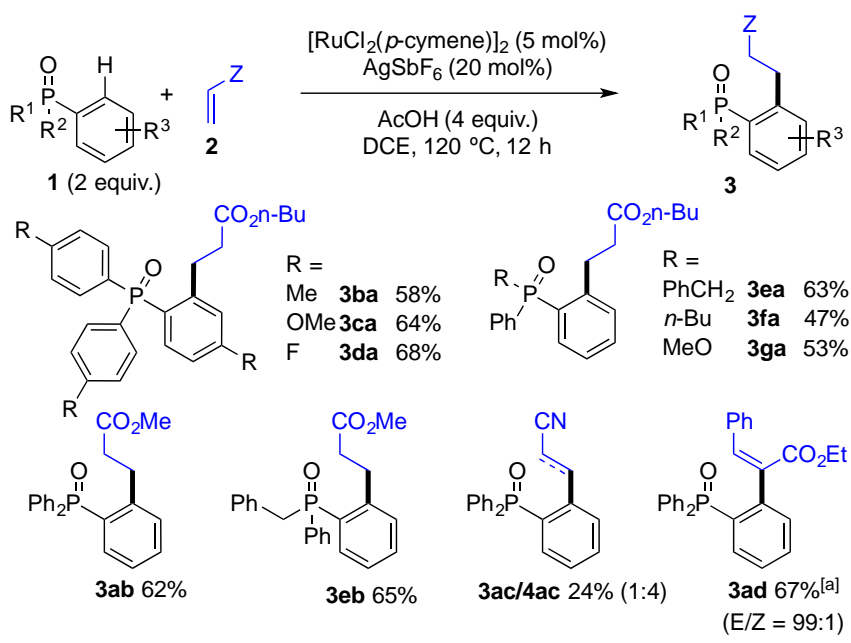

[a] reaction performed from ethyl 3-phenylpropiolate

Scheme 2. Scope of $\mathrm{Ru}(\mathrm{II})$-catalyzed $\mathrm{C}-\mathrm{H}$ bond alkylation of arylphosphine oxides.

We next examined the possibility of accessing bifunctional phosphine ligands with a pendent carboxylate, as some 
hemiaminal phosphine carboxylates have been used in catalysis. ${ }^{[22]}$ Free carboxylic acids have been shown to be critical in metal-catalyzed $\mathrm{C}-\mathrm{H}$ bond activation. ${ }^{[23]}$ The phosphine oxide carboxylate compound 5aa was obtained in $75 \%$ yield through a saponification of the ester moiety using $\mathrm{KOH}$. The reduction of phosphine oxide is well documented, ${ }^{[24]}$ and we selected the conditions described by Werner; ${ }^{[24]}$ using phenylsilane as reducing agent in the presence of catalytic amount of triflic acid, the phosphine oxide carboxylate compound 5aa was converted into the phosphine carboxylate 6 aa in $67 \%$ yield (Scheme 3 ). Using this protocol, additional phosphine carboxylates $6 \mathbf{b a}$ and $6 \mathrm{ca}$ were prepared in $42 \%$ and $63 \%$ overall yields over the two steps.

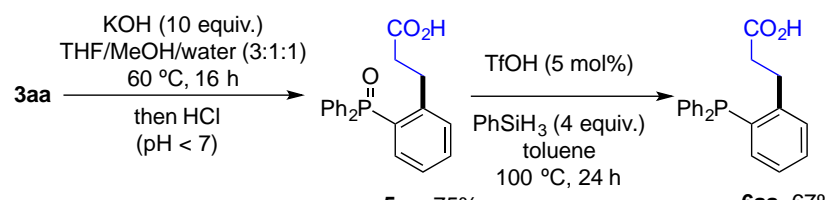

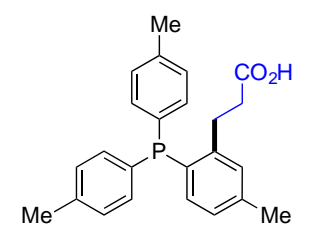

6ba $42 \%$ (yield over two steps) 5aa $75 \%$ $100^{\circ} \mathrm{C}, 24 \mathrm{~h}$

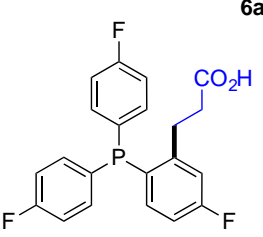

6ca $63 \%$ (yield over two steps)
Scheme 3. Preparation of bifunctional phosphine ligands.

Using the second set of ruthenium conditions favouring the formation of the alkenylation pathway (i.e., $\mathrm{NaHCO}_{3}$ in concert with $\left.\mathrm{Cu}(\mathrm{OAc})_{2} \cdot \mathrm{H}_{2} \mathrm{O}\right)$, we synthetized a couple of alkenylated aryl phosphine oxides (Scheme 4). Reaction of triphenylphosphine oxide (1a) with ethyl acrylate (2e) gave the ortho-alkenylation product 4 ae in $42 \%$ yield. The alkenylation reaction seems to be slightly sensitive to the electronic factors. Indeed tris( $p$-substituted phenyl)phosphine oxide with an electron-donating group such as methyl was alkenylated in the presence of $n$-butyl acrylate to deliver the $\mathbf{4 b a}$ in only $38 \%$ yield. Whereas, an electron-withdrawing group on the aryl phosphine oxide such as a fluoro substituent allowed the formation of $4 \mathrm{da}$ in $47 \%$ yield. For this alkenylation in basic media, it was known that the use of $\mathrm{Cu}(\mathrm{OAc})_{2} . \mathrm{H}_{2} \mathrm{O}$ is requited.

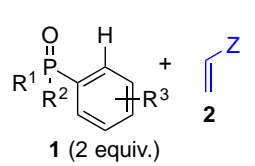

$$
\begin{gathered}
{\left[\mathrm{RuCl}_{2}(p \text {-cymene })\right]_{2}(5 \text { mol\%) }} \\
\mathrm{AgSbF}_{6}(20 \text { mol\%) }
\end{gathered}
$$
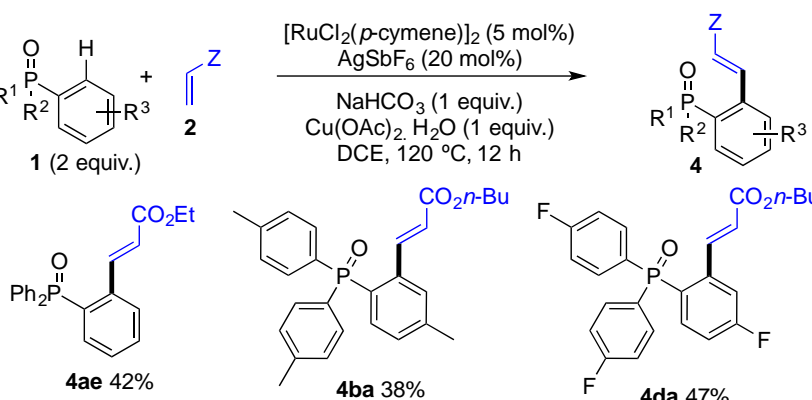

Scheme 4. Scope of Ru(II)-catalyzed C-H bond alkenylation of arylphosphine oxides.

Based on our observation and the literature, ${ }^{[20 d, 25]}$ we propose the mechanism shown in Scheme 5. The reaction of $\left[\mathrm{RuCl}_{2}(p \text {-cymene })\right]_{2}$ with $\mathrm{AgSbF}_{6}$ in the presence of $\mathrm{AcOH}$ generates ionic ruthenium(II) complex ([RuL $\left.\left.{ }_{3}(\mathrm{OAc})\right] \mathrm{X}\right)$. The oxygen atom coordination of phosphine oxide leads to the 16-electron intermediate $\mathbf{B}$, and subsequent external acetate-promoted deprotonation allows the formation of the ruthenacycle $\mathbf{C}$ and $\mathbf{A c O H} .{ }^{[23,26]}$ Coordination of alkene in $\mathbf{D}$ and insertion into the Ru-C bond affords the intermediate $\mathbf{E}$. In absence of base and due to the coordination ability of the $\mathrm{P}=\mathrm{O}$ bond, avoiding classical $\beta-\mathrm{H}$ elimination, protodemetallation affords the linear alkylation product 3 and regenerates the salt $\left[\mathrm{RuL}_{3}(\mathrm{OAc})\right] \mathrm{X}$. On the other hand, in the presence of base $\left(\mathrm{NaHCO}_{3}\right)$ the intermediate $\mathbf{E}$ undergoes a base-assisted $\beta-\mathrm{H}$ deprotonation to form the alkenylation product 4. ${ }^{[20 \mathrm{~d}, 27]}$ This deprotonation in basic medium generates $\mathrm{Ru}(0)$ species and $\mathrm{Cu}(\mathrm{OAc})_{2}$ reoxidize it into $\mathrm{Ru}(\mathrm{II})$ species. Starting from a ketone as directing group (see $\mathrm{SI}$ ), the corresponding intermediate $\mathbf{E}$ could undergo a decoordination of the ketone oxygen atom to make possible the classical $\beta-\mathrm{H}$ elimination and thus alkenylation.

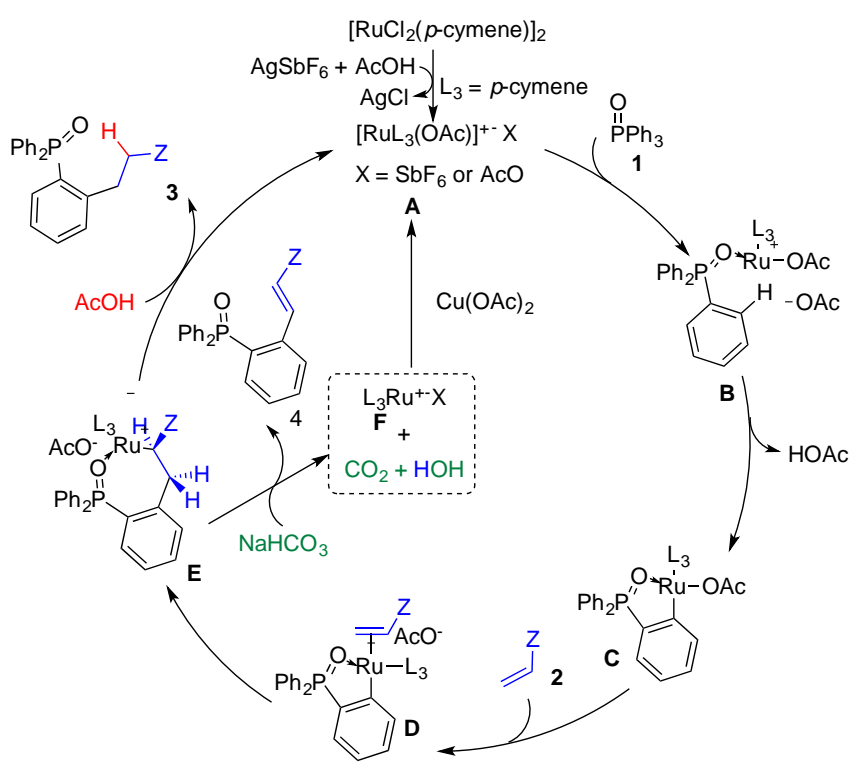


An interesting ruthenium(II)-catalyzed $\mathrm{C}-\mathrm{H}$ bond alkylation of aryl phosphine oxides with different Michael acceptors has been developed. The reaction requires the presence of acid to selectively obtain the alkylation products without reoxidizing agent, whereas the presence of a base promotes the formation of alkenylation products. Notably, after phosphine oxide reduction, phosphine carboxylate derivatives were obtained in good yields. Further applications in catalysis of bifunctional phosphine ligands bearing a pendent carboxylate are on-going in our laboratory.

\section{Acknowledgements}

We acknowledge the China Scholarship Council (CSC) for a grant to CSW.

Keywords: Aryl phosphine oxides $\cdot \mathrm{C}-\mathrm{H}$ bond Activation • Alkylation • Ruthenium(II) • Bifunctional phosphine ligands

[1] (a) A. B. Padmaperuma, L. S. Sapochak, P. E. Burrows, Chem. Mater 2006, 18, 2389-2396; (b) S. O. Jeon, K. S. Yook, C. W. Joo, J. Y. Lee, Adv. Mater. 2010, 22, 1872-1876; (c) N. Lin, J. Qiao, L. Duan, H. Li, L. Wang, Y. Qiu, J. Phys. Chem. C 2012, 116, 19451-19457; (d) D. Zhang, W. Shen, X. Zhang H. Sun, R. He, M. Li, RSC Advances 2016, 6, 35416-35424.

[2] T. S. Elliott, A. Slowey, Y. Ye, S. J. Conway, MedChemComm 2012, 3, 735-751.

[3] (a) K.-H. Lam, C.-H. Chui, R. Gambari, R. S.-M. Wong, G. Y.-M. Cheng F.-Y. Lau, P. B.-S. Lai, S.-W. Tong, K.-W. Chan, W.-Y. Wong, A. S.-C. Chan, J. C.-O. Tang, Eur. J. Med. Chem. 2010, 45, 5527-5530; (b) S. H.-I. Kok, W.-s. Lam, A. S.-c. Chan, W.-y. Wong, R. Gambari, R. S.-m. Wong, K. K.-h. Lee, J. C.-o. Tang, K.-h. Lam, C.-h. Chui, MedChemComm 2011, 2, 881-885

[4] (a) K. Mikami, M. Yamaoka, Tetrahedron Lett. 1998, 39, 4501-4504; (b) C. Ogawa, M. Sugiura, S. Kobayashi, Angew. Chem. Int. Ed. 2004, 43, 64916493; (c) N. Pinto, P. Retailleau, A. Voituriez, A. Marinetti, Chem. Commun 2011, 47, 1015-1017; (d) Y. Shimoda, S. Kotani, M. Sugiura, M. Nakajima, Chem. Eur. J. 2011, 17, 7992-7995; (e) M. Gicquel, C. Gomez, P. Retailleau, A Voituriez, A. Marinetti, Org. Lett. 2013, 15, 4002-4005.

[5] G. Y. Li, Angew. Chem. Int. Ed. 2001, 40, 1513-1516. 10, 1064-1096.

[7] (a) F. Kakiuchi, T. Kochi, Synthesis 2008, 3013-3039; (b) L. Ackermann R. Vicente, A. R. Kapdi, Angew. Chem. Int. Ed. 2009, 48, 9792-9826; (c) T. Satoh, M. Miura, Synthesis 2010, 3395-3409; (d) B.-J. Li, Z.-J. Shi, Chem. Soc. Rev. 2012, 41, 5588-5598; (e) P. B. Arockiam, C. Bruneau, P. H. Dixneuf, Chem. Rev. 2012, 112, 5879-5918; (f) J. Yamaguchi, A. D. Yamaguchi, K. Itami, Angew. Chem. Int. Ed 2012, 51, 8960-9009; (g) S. I. Kozhushkov, L. Ackermann, Chem. Sci. 2013, 4, 886-896; (h) B. Li, P. H. Dixneuf, Chem. Soc. Rev. 2013, 42, 5744 5767; (i) M. Zhang, Y. Zhang, X. Jie, H. Zhao, G. Li, W. Su, Org. Chem. Front. 2014, 1, 843-895; (j) M. R. Yadav, R. K. Rit, M. Shankar, A. K. Sahoo, Asian J. Org. Chem. 2015, 4, 846-864; (k) C. B. Bheeter, L. Chen, J.-F. Soulé, H. Doucet, Catal. Sci. Technol. 2016, 6, 2005-2049.

[8] For recent exemples of ruthenium(II)-catalyzed $\mathrm{C}-\mathrm{H}$ bond fonctionalizations, see: (a) L. Huang, A. Biafora, G. Zhang, V. Bragoni, L. J. Gooßen, Angew. Chem. Int. Ed. 2016, 55, 6933-6937; (b) M. Simonetti, G. J. P. Perry, X. C. Cambeiro, F. Juliá-Hernández, J. N. Arokianathar, I. Larrosa, J. Am. Chem. Soc. 2016, 138, 3596-3606; (c) Y. Koseki, K. Kitazawa, M. Miyake, T. Kochi, F. Kakiuchi, J. Org. Chem. 2016.

[9] S. Takebayashi, T. Shibata, Organometallics 2012, 31, 4114-4117.

[10] D.-W. Gao, Q. Gu, C. Zheng, S.-L. You, Acc. Chem. Res. 2017, 50, $351-$

365

[11] Y. Unoh, Y. Hashimoto, D. Takeda, K. Hirano, T. Satoh, M. Miura, Org Lett. 2013, 15, 3258-3261.

[12] D. Zhao, C. Nimphius, M. Lindale, F. Glorius, Org. Lett. 2013, 15, 4504 4507.

[13] (a) Y. Park, I. Jeon, S. Shin, J. Min, P. H. Lee, J. Org. Chem. 2013, 78, 10209-10220; (b) Y. Park, J. Seo, S. Park, E. J. Yoo, P. H. Lee, Chem. - Eur. J. 2013, 19, 16461-16468; (c) J. Seo, Y. Park, I. Jeon, T. Ryu, S. Park, P. H. Lee, Org. Lett. 2013, 15, 3358-3361.
[14] (a) S. Park, B. Seo, S. Shin, J.-Y. Son, P. H. Lee, Chem. Commun. 2013 49, 8671-8673; (b) T. T. Nguyen, L. Grigorjeva, O. Daugulis, ACS Catal. 2016 $6,551-554$.

[15] D. Gwon, D. Lee, J. Kim, S. Park, S. Chang, Chem. - Eur. J. 2014, 20 , 12421-12425.

[16] (a) K. Baba, M. Tobisu, N. Chatani, Angew. Chem. Int. Ed. 2013, 52 11892-11895; (b) Y. Unoh, T. Satoh, K. Hirano, M. Miura, ACS Catal. 2015, 5 6634-6639; (c) K. Baba, M. Tobisu, N. Chatani, Org. Lett. 2015, 17, 70-73. [17] L.-J. Gu, C. Jin, R. Wang, H.-Y. Ding, ChemCatChem 2014, 6, 1225 1228.

[18] M. Itoh, Y. Hashimoto, K. Hirano, T. Satoh, M. Miura, J. Org. Chem. 2013 78, 8098-8104.

[19] (a) H. Weissman, X. Song, D. Milstein, J. Am. Chem. Soc. 2001, 123 337-338; (b) T. Ueyama, S. Mochida, T. Fukutani, K. Hirano, T. Satoh, M. Miura Org. Lett. 2011, 13, 706-708; (c) P. B. Arockiam, C. Fischmeister, C. Bruneau, P. H. Dixneuf, Green Chem. 2011, 13, 3075-3078; (d) Y. Hashimoto, T. Ueyama, T. Fukutani, K. Hirano, T. Satoh, M. Miura, Chem. Lett. 2011, 40, 1165-1166. [20] (a) M. Schinkel, I. Marek, L. Ackermann, Angew. Chem. Int. Ed. 2013 52, 3977-3980; (b) J. Qi, L. Huang, Z. Wang, H. Jiang, Org. Biomol. Chem. 2013, 11, 8009-8013; (c) Y. Kommagalla, K. Srinivas, C. V. Ramana, Chem. Eur. J. 2014, 20, 7884-7889; (d) Y. Kommagalla, V. B. Mullapudi, F. Francis, C. V. Ramana, Catal. Sci. Technol. 2015, 5, 114-117.

[21] (a) T. Ryu, J. Kim, Y. Park, S. Kim, P. H. Lee, Org. Lett. 2013, 15, 3986 3989; (b) J. Mo, S. Lim, S. Park, T. Ryu, S. Kim, P. H. Lee, RSC Adv. 2013, 3 18296-18299.

[22] (a) E. N. Tsvetkov, N. A. Bondarenko, I. G. Malakhova, M. I. Kabachnik, Synthesis 1986, 198-208; (b) G. J. P. Britovsek, W. Keim, S. Mecking, D. Sainz, T. Wagner, J. Chem. Soc., Chem. Commun. 1993, 1632-1634; (c) R. S. Dickson, T. De Simone, E. M. Campi, W. R. Jackson, Inorg. Chim. Acta 1994, 220, 187192; (d) H. Wang, Q. Deng, Z. Zhou, S. Hu, Z. Liu, L.-Y. Zhou, Org. Lett. 2016, 18, 404-407; (e) H. Hu, S. Yu, L. Zhu, L. Zhou, W. Zhong, Org. Biomol. Chem. 2016, 14, 752-760

[23] E. Ferrer Flegeau, C. Bruneau, P. H. Dixneuf, A. Jutand, J. Am. Chem. Soc. 2011, 133, 10161-10170.

[24] (a) T. Coumbe, N. J. Lawrence, F. Muhammad, Tetrahedron Lett. 1994 35, 625-628; (b) C. A. Busacca, R. Raju, N. Grinberg, N. Haddad, P. JamesJones, H. Lee, J. C. Lorenz, A. Saha, C. H. Senanayake, J. Org. Chem. 2008 73, 1524-1531; (c) Y. Li, L.-Q. Lu, S. Das, S. Pisiewicz, K. Junge, M. Beller, J. Am. Chem. Soc. 2012, 134, 18325-18329; (d) K. V. Rajendran, D. G. Gilheany Chem. Commun. 2012, 48, 817-819; (e) S. S. Al Sulaimi, K. V. Rajendran, D. G. Gilheany, Eur. J. Org. Chem. 2015, 2015, 5959-5965; (f) M.-L. Schirmer, S. Jopp, J. Holz, A. Spannenberg, T. Werner, Adv. Synth. Catal. 2016, 358, 26-29. [25] (a) D. L. Davies, O. Al-Duaij, J. Fawcett, M. Giardiello, S. T. Hilton, D. R Russell, Dalton Trans. 2003, 4132-4138; (b) Y. Boutadla, D. L. Davies, S. A Macgregor, A. I. Poblador-Bahamonde, Dalton Trans. 2009, 5820-5831; (c) K Padala, M. Jeganmohan, Org. Lett. 2011, 13, 6144-6147.

[26] I. Fabre, N. von Wolff, G. Le Duc, E. Ferrer Flegeau, C. Bruneau, P. H. Dixneuf, A. Jutand, Chem. Eur. J. 2013, 19, 7595-7604.

[27] C. Bruneau, P. H. Dixneuf, in Top. Organomet. Chem. , Vol. 55, Springer, 2015, pp. 137-188. 


\section{Layout 2:}

\section{FULL PAPER}

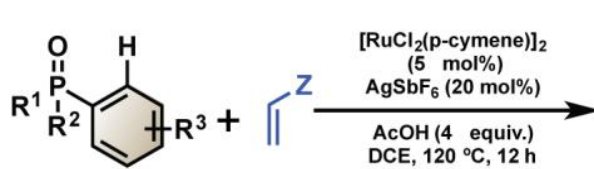

$\mathrm{P}=\mathrm{O}$ acts as a directing group<smiles>[Z]CCc1ccccc1P([R])(C)=O</smiles>

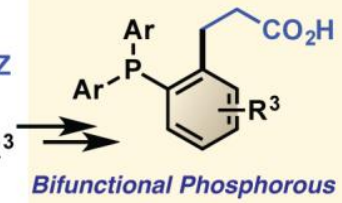

Ligands

Ruthenium(II)-catalyzed $\mathrm{C}-\mathrm{H}$ bond alkylaion of arylphosphine oxide with functional alkenes has been developed. The use of acetic acid was found to be critical to favor the formation of the alkylation products while the use of $\mathrm{NaHCO}_{3}$ affords alkenylation products. This method allows the desymmetrization of diarylphosphine oxides. After reduction of the phosphine oxide, novel phosphines bearing a flexible pendent carboxylate were synthetized.

C.-S. Wang, P. H. Dixneuf* and J.-F. Soulé*

Page No. - Page No.

Ruthenium-Catalyzed C-H Bond Alkylation of Arylphosphine Oxides with Alkenes: A Straightforward Access to Bifunctional Phosphorous Ligands with a Pendent Carboxylate 